Artikel Penelitian

\title{
Analisis Kadar Timbal (Pb) pada Bedak Tabur dan Eyeshadow dengan Variasi Metode Destruksi dan Zat Pengoksidasi dengan Spektroskopi Serapan Atom
}

\author{
Diana Candra Dewi, Rif'atul Mahmudah, Oktrin Rustika Kumalawati, Diana Amalullia
}

Jurusan Kimia, Fakultas Sains dan Teknologi, Universitas Islam Negeri Maulana Malik Ibrahim, Malang, Indonesia, 65144

\section{INFO ARTIKEL}

\section{Riwayat Artikel}

Direvisi 27 Februari 2019

Diterima 25 Maret 2019

Tersedia online 21 Mei 2019

\section{ABSTRAK}

Loose powder and eyeshadow are cosmetics often used by women in their daily activities. Some cosmetic products contain heavy metal in the composition. This study aims to determine the concentration of lead in the loose powder and eyeshadow both registered and unregistered at the Food and Drug Supervisory Agency (BPOM) in Malang. The destruction method used is wet digestion in the opened and closed systems with variations of oxidizing agents of $\mathrm{HNO}_{3}$ and $\mathrm{HClO}_{4}$. The concentration of lead was analyzed using atomic absorption spectroscopy (AAS). The results of destruction optimization on loose powder and eyeshadow showed wet digestion in closed system gave the best destruction results. The best oxidizing agent for both products is a mixture of $\mathrm{HNO}_{3}: \mathrm{HClO}_{4}$ (2: 1). Lead concentration in the loose powder product for samples $A, B, C, D$ was $18.90 \pm 0.35,19.10 \pm 0.46,23.47 \pm 0.65$ and $28.90 \pm 0.35 \mathrm{mg} / \mathrm{Kg}$, respectively. Eyeshadow samples of $E, F, G$, and $H$ contained lead concentrations were $25.67 \pm 1.76,34.23 \pm 0.57,45.30 \pm 0.56$ and $45.90 \pm 1.78 \mathrm{mg} / \mathrm{Kg}$, respectively.

Keywords: cosmetics, loose powder, eyeshadow, lead

Bedak tabur dan eyeshadow merupakan kosmetik yang sering digunakan oleh wanita dalam kehidupaan sehari-hari. Beberapa produk kosmetik mengandung logam berat dalam komposisinya. Penelitian ini bertujuan untuk menentukan kadar timbal pada bedak tabur dan eyeshadow baik yang terdaftar dan tidak terdaftar di Badan Pengawas Obat dan Makanan (BPOM) di kota Malang. Metode yang digunakan adalah metode destruksi basah (terbuka dan tertutup) dengan variasi zat pengoksidasi $\mathrm{HNO}_{3}$ dan $\mathrm{HClO}_{4}$. Kadar timbal dianalisis menggunakan spektroskopi serapan atom (SSA). Hasil optimasi desktruksi pada bedak tabur dan eyeshadow menunjukkan bahwa destruksi basah tertutup memberikan hasil destruksi terbaik. Adapun pengoksidasi terbaik untuk kedua produk tersebut adalah campuran $\mathrm{HNO}_{3}: \mathrm{HClO}_{4}(2: 1)$. Kadar timbal bedak tabur

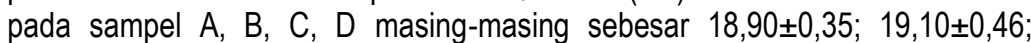
$23,47 \pm 0,65$ dan $28,90 \pm 0,35 \mathrm{mg} / \mathrm{Kg}$. Sampel eyeshadow E, F, G, dan $\mathrm{H}$ mengandung kadar timbal sebesar $25,67 \pm 1,76 ; 34,23 \pm 0,57 ; 45,30 \pm 0,56$ dan $45,90 \pm 1,78 \mathrm{mg} / \mathrm{Kg}$, berturut-turut.

Kata kunci: kosmetik, bedak tabur, eyeshadow, timbal 


\section{Pendahuluan}

Peningkatan penggunaan kosmetik menyebabkan peningkatan produksi dan penyebaran kosmetik di Indonesia. Fungsi utama penggunaan kosmetik yaitu untuk mempercantik diri pengguna agar tampak lebih menarik [1]. Jenis sediaan kosmetik yang banyak digunakan adalah bedak tabur dan perona kelopak mata (eyeshadow) dimana produk kosmetik tersebut mengandung pigmen warna. Beberapa produk kosmetik mengandung logam berat seperti timbal, arsen, merkuri, kobal, dan nikel yang digunakan sebagai bahan dasar atau pengotor [2].

Beberapa penelitian telah membuktikan bahwa logam berat yang terdapat pada kosmetik dapat menyebabkan gangguan kulit sehingga penggunaan logam berat dalam kosmetik telah dilarang di beberapa negara. Penambahan timbal pada pembuatan beberapa produk bedak tabur dan eyeshadow sengaja ditambahkan sebagai pigmen warna [3]. Peraturan Kepala Badan Pengawas Obat dan Makanan Republik Indonesia Nomor 17 Tahun 2014 menyatakan bahwa batas aman cemaran logam berat (timbal) dalam kosmetik adalah tidak lebih dari $20 \mathrm{mg} / \mathrm{kg}$ [4].

Penentuan logam timbal pada kosmetik seperti bedak dan eyeshadow telah dilakukan. Yebpella dkk. [5] melaporkan bahwa kadar timbal dalam bedak dan eyeshadow di Nigeria masing-masing sebesar 0,6866 dan 0,0254 mg/Kg. Nnorom [6] meneliti kadar timbal pada facial talcum powder di Nigeria dan diperoleh kadar timbal sebesar 5,0 $00,1 \mathrm{mg} / \mathrm{Kg}$, sedangkan Ekere dkk. [7] telah meneliti kadar timbal pada bedak sebesar 0,10 $\pm 0,015 \mathrm{mg} / \mathrm{Kg}$. Omolaoye dkk. [8] menyebutkan kadar timbal dalam eyeshadow berbagai warna adalah $8,33-18,89 \mathrm{mg} / \mathrm{Kg}$. Faruruwa \& Bartholomew [9] menemukan tidak ada kadar timbal pada bedak dan menemukan kadar timbal sebesar $3,70 \mathrm{mg} / \mathrm{kg}$ pada eyeshadow.

Penelitian mengenai penentuan kadar timbal pada bedak tabur dan eyeshadow di Indonesia belum banyak dilakukan. Analisis ini perlu dilakukan pada kosmetik mengingat bahaya yang diakibatkan yaitu memiliki toksisitas kronis dan akut. Penelitian ini bertujuan menentukan kadar timbal pada bedak tabur dan eyeshadow menggunakan spektroskopi serapan atom (SSA) yang diambil berbagai merek baik yang terdaftar BPOM dan merek yang tidak terdaftar BPOM. Pada penelitian ini juga dilakukan variasi metode destruksi basah dan zat pengoksidasi $\mathrm{HNO}_{3}: \mathrm{HClO}_{4}$.

\section{Bahan dan Metode}

\subsection{Bahan}

Sampel penelitian adalah bedak tabur dan eyeshadow yang dibeli dari toko kosmetik di kota Malang. Adapun bahan kimia yang digunakan adalah $\mathrm{Pb}\left(\mathrm{NO}_{3}\right)_{2}$ (Merck), $\mathrm{HNO}_{3} 65 \%$ (Merck), $\mathrm{HClO}_{4} 60 \%$ (Merck) dan akuades.

\subsection{Pemilihan Sampel}

Sampel bedak tabur yang digunakan ada 4 produk yang ditandai dengan kode $A, B, C$, dan $D$. Dua produk bedak tabur terdaftar di BPOM, sedangan dua produk sisanya tidak terdaftar di BPOM. Adapun sampel eyeshadow yang digunakan ada 4 produk yang ditandai dengan kode $E, F, G$ dan $H$ dimana sampel $F$ dan $H$ terdaftar dan sampel $E$ dan $G$ tidak terdaftar di BPOM. Warna bedak tabur yang dipilih adalah kuning kecoklatan, sedangkan warna eyeshadow yang dipilih adalah hitam (E, F) dan hijau (G, H).

\subsection{Pembuatan Kurva Standar Timbal (Pb)}

Kurva standar timbal dibuat pada konsentrasi $0 ; 0,1 ; 0,2 ; 0,4 ; 0,8$ dan 1,4 mg/L. Absorbansi larutan standar diukur menggunakan spektroskopi serapan atom (SSA Varian Spectra AA 240) pada panjang gelombang $217 \mathrm{~nm}$. Kondisi optimum SSA yaitu lebar celah 1,0 nm; arus lampu katoda 10,0 $\mu \mathrm{A}$; laju alir udara 10,0 L/menit, dan laju alir asetilen 2,0 L/menit.

\subsection{Penentuan Metode Destruksi dan Zat Pengoksidasi Terbaik}

\subsubsection{Destruksi Basah Terbuka}

Sebanyak $0,5 \mathrm{~g}$ sampel dan ditambahkan $30 \mathrm{~mL}$ zat pengoksidasi. Sampel yang digunakan adalah campuran bedak tabur dari keempat produk dan campuran eyeshadow dari keempat produk. Zat pengoksidasi yang digunakan adalah $\mathrm{HNO}_{3}$ dan campuran $\mathrm{HNO}_{3}$ dengan $\mathrm{HClO}_{4}$. Perbandingan campuran $\mathrm{HNO}_{3}$ dan $\mathrm{HClO}_{4}$ adalah 2:1, 3:1, 4:1, dan 5:1. Sampel dipanaskan di atas hotplate pada suhu $100^{\circ} \mathrm{C}$ hingga volumenya berkurang dan larutan berwarna jernih. Larutan hasil destruksi didinginkan pada suhu ruang kemudian disaring menggunakan kertas Whatman No.42. Hasil penyaringan diencerkan dengan $\mathrm{HNO}_{3} 0,5 \mathrm{M}$ dalam labu ukur $20 \mathrm{~mL}$. Konsentrasi timbal $(\mathrm{Pb})$ ditentukan menggunakan $\mathrm{SSA}$.

\subsubsection{Destruksi Basah Tertutup}

Sampel sebanyak $0,5 \mathrm{~g}$ ditambahkan $30 \mathrm{~mL}$ zat pengoksidasi. Zat pengoksidasi yang digunakan sama seperti pada destruksi basah terbuka. Sampel dipanaskan dalam refluks pada suhu $100^{\circ} \mathrm{C}$ sampai larutan berwarna jernih. Larutan 
hasil destruksi didinginkan pada suhu ruang dan disaring dengan kertas Whatman No.42. Hasil penyaringan diencerkan dalam labu ukur $50 \mathrm{~mL}$ dengan $\mathrm{HNO}_{3} 0,5 \mathrm{M}$ dan diukur konsentrasi timbal $(\mathrm{Pb})$ menggunakan SSA.

\subsection{Analisis Kadar Timbal $(P b)$ pada Sampel}

Analisis kadar timbal $(\mathrm{Pb})$ pada sampel digunakan metode destruksi basah terbaik. Sebanyak $0,5 \mathrm{~g}$ sampel ditambah dengan $30 \mathrm{~mL}$ zat pengoksidasi terbaik. Sampel dipanaskan pada suhu $100^{\circ} \mathrm{C}$ hingga jernih dan larutan hasil destruksi didinginkan pada suhu ruang. Larutan destruksi disaring dengan kertas Whatman No.42, diencerkan dengan $\mathrm{HNO}_{3}$ 0,5 M dan ditentukan konsentrasi timbal (Pb) dengan SSA. Persamaan regresi kurva standar diperoleh dari ploting nilai absorbansi terhadap kadar logam yang terbaca oleh instrumen. Kadar logam $\mathrm{Pb}$ pada sampel ditentukan menggunakan Persamaan 1.

$$
\text { Kadar logam } \mathrm{Pb}(\mathrm{mg} / \mathrm{Kg})=\frac{\text { Kadar yang terbaca instrumen } \mathrm{x} \text { volume larautan }}{\text { Berat sampel }}
$$

\section{Hasil dan Pembahasan}

\subsection{Kurva Standar Timbal $(P b)$}

Kurva standar bertujuan mengetahui hubungan antara konsentrasi larutan dengan nilai absorbansi sampel sehingga konsentrasi sampel dapat diketahui. Nilai koefisien relasi $\left(R^{2}\right)$ mendeskripsikan linearitas kurva standar, dimana $R^{2}$ yang mendekati 1 menunjukkan kemiringan yang positif $\left(R^{2}=0,9807\right)$. Berdasarkan nilai $R^{2}$, kurva standar dalam keadaan baik. Persamaan regresi yang diperoleh adalah $y=0,0458 x+0,0039$ (Gambar 1).

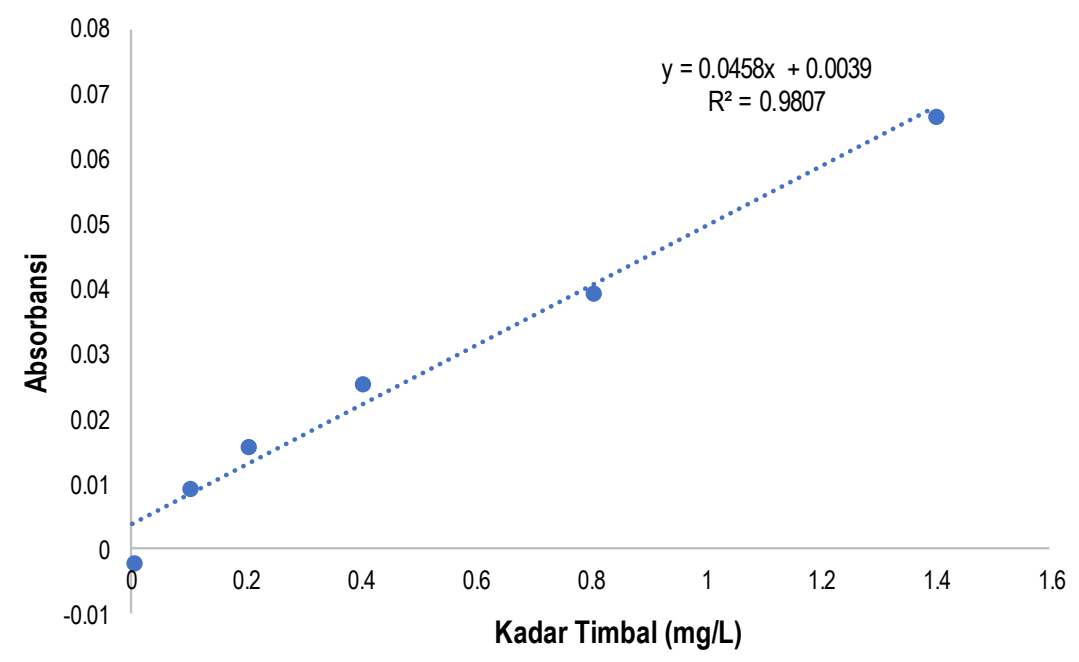

Gambar 1. Kurva standar timbal $(\mathrm{Pb})$

\subsection{Penentuan Metode Destruksi dan Zat Pengoksidasi Terbaik}

Destruksi basah adalah proses perombakan atau pemutusan senyawa organik dalam sampel menggunakan larutan pengoksidasi berupa larutan asam baik tunggal atau campuran pada suhu pemanasan tertentu. Pada penelitian ini digunakan dua jenis destruksi yaitu destruksi basah terbuka dan tertutup. Destruksi basah terbuka dilakukan menggunakan gelas kimia, sedangkan destruksi basah tertutup dilakukan menggunakan refluks [10, 11]. Pemanasan dalam proses destruksi bertujuan untuk mempercepat pemutusan ikatan senyawa dalam sampel [12].

Jenis metode destruksi dan larutan pengoksidasi penting dalam proses destruksi sampel. Berdasarkan Gambar 2 dan 3, destruksi basah tertutup merupakan zat pengoksidasi terbaik. Kadar timbal pada destruksi basah terbuka sebesar $19,91 \pm 0.09-29,28 \pm 1,85 \mathrm{mg} / \mathrm{Kg}$ untuk campuran bedak tabur dan $11,76 \pm 1,31-17,60 \pm 1,88 \mathrm{mg} / \mathrm{Kg}$ untuk sampel campuran eyeshadow, sedangkan pada destruksi basah tertutup sebesar $39,93 \pm 3,26-83,97 \pm 2,90 \mathrm{mg} / \mathrm{Kg}$ untuk sampel campuran bedak tabur dan $24,93 \pm 0,51-33,47 \pm 3,46 \mathrm{mg} / \mathrm{Kg}$ untuk sampel campuran eyeshadow. Destruksi basah tertutup dapat menghasilkan kadar timbal yang tinggi dimungkinkan karena sistem tertutup relatif memberikan tekanan yang lebih besar sehingga mempercepat pemutusan ikatan senyawa organik pada sampel. 


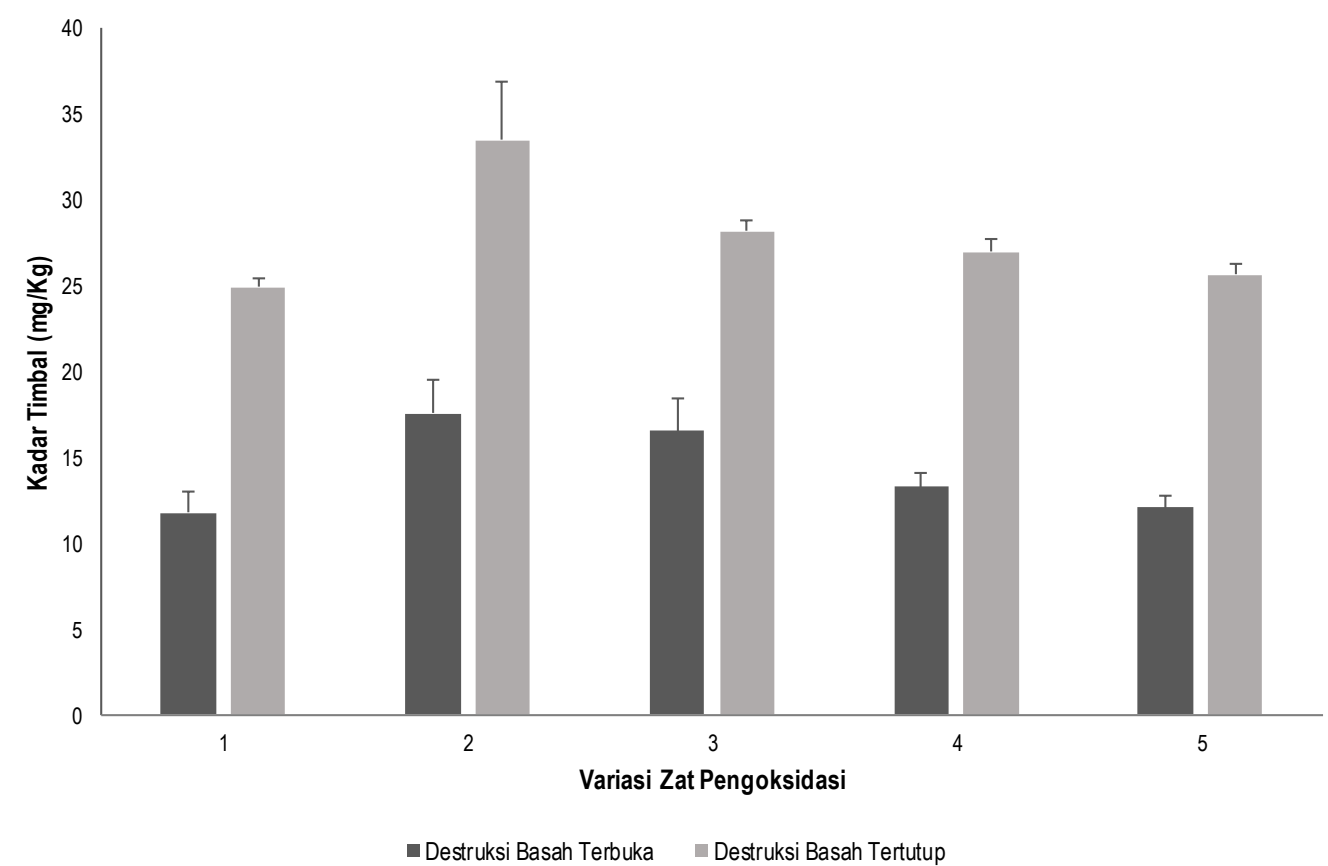

Gambar 2. Kadar timbal pada campuran bedak tabur dengan metode destruksi basah terbuka dan tertutup. Variasi zat pengoksidasi dari nomor 1 - 5 adalah $\mathrm{HNO}_{3}, \mathrm{HNO}_{3}: \mathrm{HClO}_{4}(2: 1), \mathrm{HNO}_{3}: \mathrm{HClO}_{4}(3: 1), \mathrm{HNO}_{3}: \mathrm{HClO}_{4}(4: 1)$, dan $\mathrm{HNO}_{3}: \mathrm{HClO}_{4}(5: 1)$.

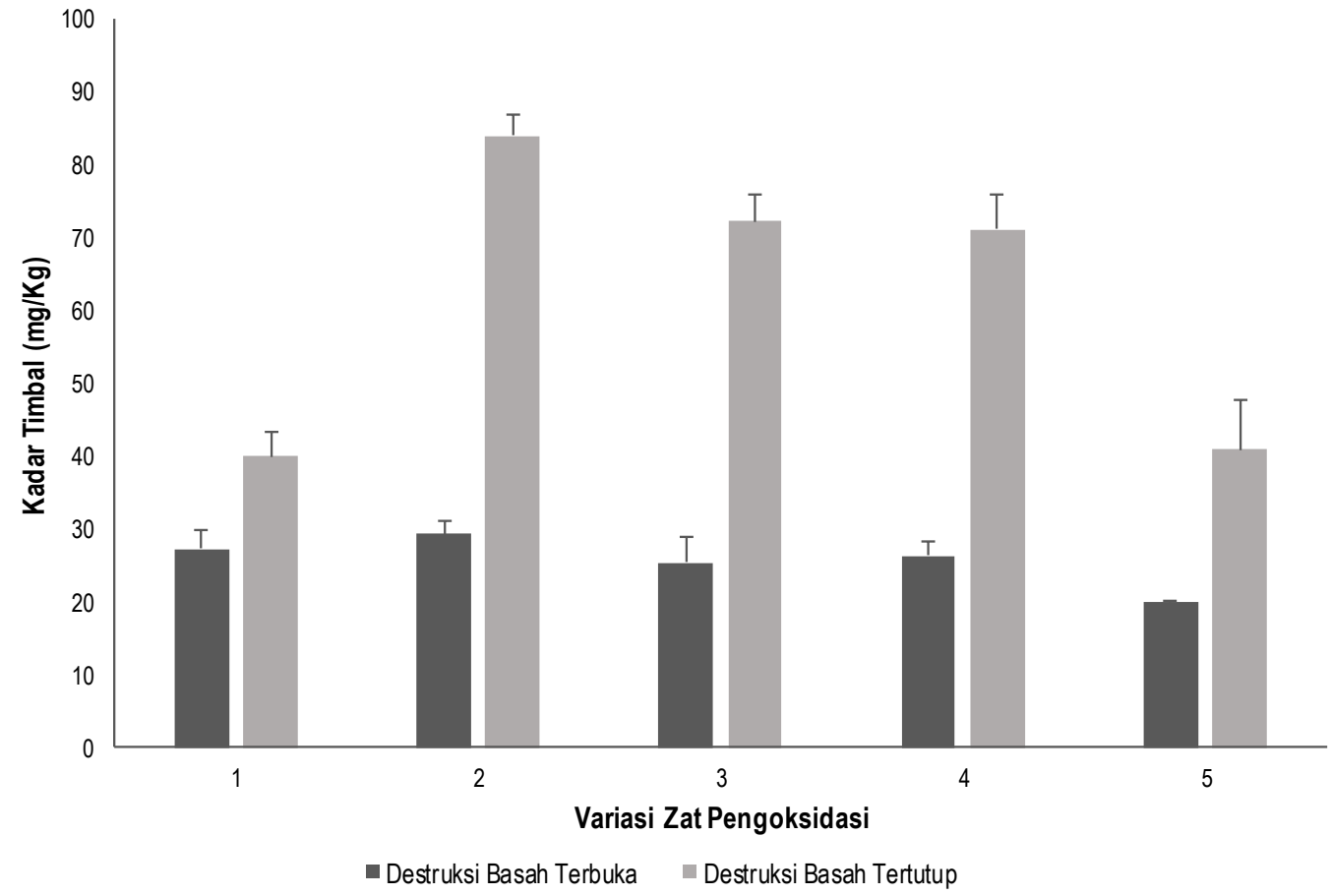

Gambar 3. Kadar timbal pada campuran eyeshadow dengan metode destruksi basah terbuka dan tertutup. Variasi zat pengoksidasi dari nomor 1 - 5 adalah $\mathrm{HNO}_{3}, \mathrm{HNO}_{3}: \mathrm{HClO}_{4}(2: 1), \mathrm{HNO}_{3}: \mathrm{HClO}_{4}(3: 1), \mathrm{HNO}_{3}: \mathrm{HClO}_{4}(4: 1)$, dan $\mathrm{HNO}_{3}: \mathrm{HClO}_{4}(5: 1)$.

Pada penelitian ini, pengoksidasi terbaik untuk mendestruksi sampel bedak tabur dan eyeshadow adalah campuran $\mathrm{HNO}_{3}: \mathrm{HClO}_{4}(2: 1)$ (Gambar 2 dan 3). Campuran zat pengoksidasi $\mathrm{HNO}_{3}: \mathrm{HClO}_{4}(2: 1)$ menghasilkan kadar timbal tertinggi yaitu sebesar $33,47 \pm 3,46 \mathrm{mg} / \mathrm{Kg}$ (campuran eyeshadow) dan $83,97 \pm 2,90 \mathrm{mg} / \mathrm{Kg}$ (campuran bedak tabur). $\mathrm{HNO}_{3}$ berfungsi sebagai agen pengoksidasi utama karena senyawa ini dalam melarutkan logam $\mathrm{Pb}$ dengan baik, sedangkan $\mathrm{HClO}_{4}$ berfungsi sebagai oksidator yang membantu $\mathrm{HNO}_{3}$ untuk mendekomposisi matrik organik pada sampel [13]. Agusti [14] dan Taufikurrahman [15] menggunakan campuran zat pengoksidasi ini untuk mendestruksi sampel. Reaksi yang terjadi saat proses destruksi ditunjukkan pada Reaksi 1 [16]. 


$$
\mathrm{Pb}(\mathrm{CHO})_{\times(\mathrm{s})}+\mathrm{HNO}_{3(\mathrm{aq})}+\mathrm{HClO}_{4(\mathrm{aq})} \rightarrow \mathrm{Pb}\left(\mathrm{NO}_{3}\right)_{x(\mathrm{aq})}+\mathrm{CO}_{2(\mathrm{~g})}+\mathrm{NO}_{2(\mathrm{~g})}+\mathrm{HClO}_{3(\mathrm{l})}
$$

\subsection{Penentuan Kadar Timbal (Pb) pada Bedak Tabur dan Eyeshadow}

Logam berat timbal terdeteksi pada semua sampel kosmetik baik sampel yang sudah terdaftar maupun yang tidak terdaftar di BPOM (Gambar 4). Peraturan Kepala Badan Pengawas Obat dan makanan Republik Indonesia Nomor 17 Tahun 2014 menyebutkan bahwa batas kadar timbal pada kosmetik adalah tidak lebih dari $20 \mathrm{mg} / \mathrm{Kg}$. Berdasarkan Gambar 4, hanya dua sampel yang memiliki tidak melebihi batas kadar timbal yaitu sampel A dan B $(18,90 \pm 0,35$ dan $19,10 \pm 0,46 \mathrm{mg} / \mathrm{Kg}$ ). Sampel A dan B adalah sampel bedak tabur yang terdaftar di BPOM. Sampel C dan D merupakan sampel bedak tabur yang tidak terdaftar di BPOM dengan kadar timbal sebesar $23,47 \pm 0,65$ dan 28,90 $\pm 0,35 \mathrm{mg} / \mathrm{Kg}$, berturut-turut. Hasil penelitian ini berbeda dengan penelitian Yugatama dkk. [17] yang menunjukkan bedak (compact

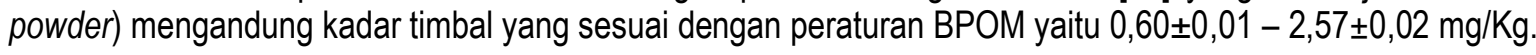

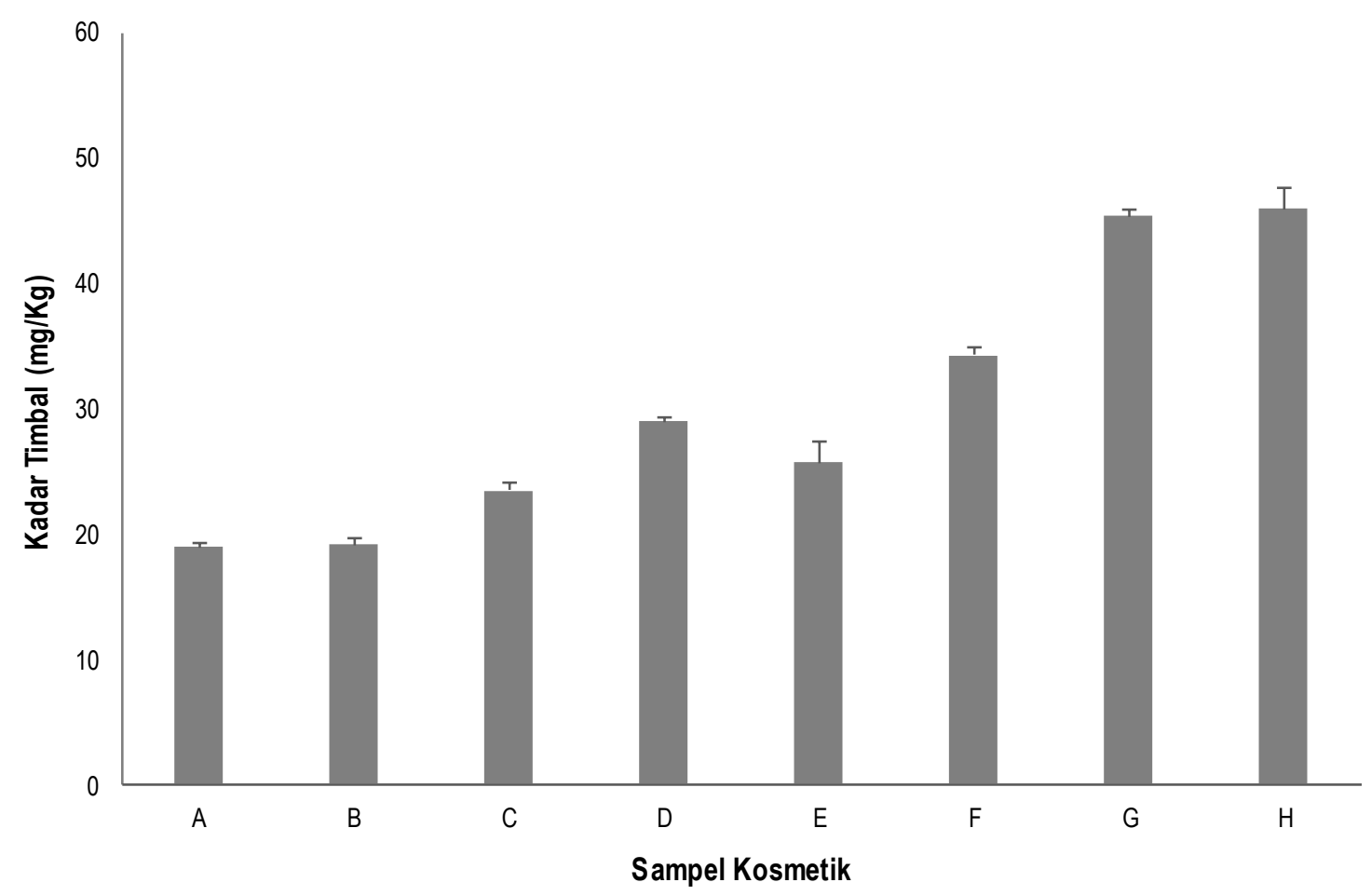

Gambar 4. Kadar timbal pada sampel bedak tabur (A, B, C, D) dan eyeshadow (E, F, G, H) dengan metode destruksi tertutup dengan zat pengoksidasi $\mathrm{HNO}_{3}: \mathrm{HClO}_{4}(2: 1)$.

Sampel E, F, G, H merupakan sampel eyeshadow dengan kadar timbal masing-masing sebesar $25,67 \pm 1,76$; $34,23 \pm 0,57 ; 45,30 \pm 0,56$ dan $45,90 \pm 1,78 \mathrm{mg} / \mathrm{Kg}$. Sampel $E$ dan $\mathrm{G}$ adalah eyeshadow yang tidak terdaftar BPOM, sedangkan sampel $\mathrm{F}$ dan $\mathrm{H}$ adalah eyeshadow yang terdaftar BPOM. Sampel $\mathrm{F}$ dan $\mathrm{H}$ mengandung kadar timbal diatas ambang batas peraturan BPOM. Hasil penelitian ini berbeda dengan penelitian Fatmawati dan Ayumulia [18]. Kadar timbal eyeshadow yang terdaftar BPOM sebesar 2,33 - 7,60 mg/Kg, sedangkan eyeshadow yang tidak terdaftar mengandung timbal sebesar $6,86-127,36 \mathrm{mg} / \mathrm{Kg}$. Kandungan timbal yang melebihi ambang batas pada eyeshadow yang terdaftar BPOM dimungkinkan karena adanya kerusakan atau kontaminasi bahan dasar yang digunakan atau kontaminasi selama proses produksi.

Sampel eyeshadow yang digunakan pada penelitian ini berwarna hitam ( $E$ dan $F)$ dan hijau ( $G$ dan $H)$. Variasi warna pada sampel dapat memberikan konstribusi terhadap kadar berat. Eyeshadow dengan warna hijau mengandung kadar logam yang lebih tinggi dibandingkan eyeshadow berwarna hitam. Kamal dkk. [19] mengatakan senyawa timbal digunakan secara luas untuk pewarna cat. Erasiska dkk. [1] menyebutkan produsen menggunakan bahan yang mengandung logam untuk memberikan warna yang lebih cerah pada produk kosmetik.

\section{Kesimpulan}

Metode destruksi basah dan zat pengoksidasi terbaik yang digunakan dalam analisis kadar timbal pada bedak tabur dan eyeshadow yaitu metode destruksi basah tertutup menggunakan refluks dengan zat pengoksidasi $\mathrm{HNO}_{3}: \mathrm{HClO}_{4}(2: 1)$. 
Kadar timbal bedak tabur pada sampel A, B, C, D masing-masing sebesar $18,90 \pm 0,35 ; 19,10 \pm 0,46 ; 23,47 \pm 0,65$ dan

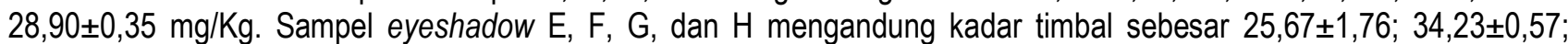
$45,30 \pm 0,56$ dan $45,90 \pm 1,78 \mathrm{mg} / \mathrm{Kg}$, berturut-turut. Kadar timbal yang tidak melebihi ambang batas berdasarkan peraturan BPOM adalah sampel A dan B.

\section{Daftar Pustaka}

[1] Erasiska, S. Bali, \& T. A. Hanifah, "Analisis Kandungan Logam Timbal, Kadmium, dan Merkuri dalam Produk Krim Pemutih Wajah," Jurnal Online Mahasiswa Fakultas Matematika dan IImu Pengetahuan Alam Universitas Riau, vol. 2, no.1, pp. 123-129, 2015.

[2] J. G. Ayenimo, A. M. Yusuf, \& A. S. Adekunle, "Heavy Metal Exposure from Personal Care Products," Bulletin of Environmental Contamination and Toxicology, vol. 84, no. 1, pp. 8-14, 2010.

[3] L. U. Tsankov, I. Iordanova, D. Lolova, S. Uzunova, \& S. Dinoeva, "Hygienic Evaluation of the Content of Heavy Metals (Lead and Copper) in Cosmetic Products," Problemina Higienata, vol. 7, pp. 127-136, 1982.

[4] Badan Pengawas Obat dan Makanan Republik Indonesia, Peraturan Kepala Badan Pengawas Obat dan Makanan Republik Indonesia Nomor HK.03.1.23.08.11.07331 tentang Metode Analisis Penetapan Kadar Cemaran Logam Berat (Arsen, Kadmium, Timbal, dan Merkuri) dalam Kosmetika. Jakarta: Badan Pengawas Obat dan Makanan, 2011.

[5] G. G. Yebpella, A. M. Magomya, U. Lawal, B. Gauje, \& O. J. Oko, "Assessment of Trace Metals in Imported Cosmetics Marketed in Nigeria," Journal of Natural Sciences Research, vol. 4, no.14, pp. 11-14, 2014.

[6] I. C. Nnorom, "Trace Metals in Cosmetic Facial Talcum Powders Marketed in Nigeria," Environmental Chemistry Technology, vol. 93, no. 6, pp. 1135-1148, 2010.

[7] N. R. Ekere, J. N. Ihedioha, T. I. Oparanozie, F. I. Ogbuefi-Chima, \& J. Ayogu, "Assessment of Some Heavy Metals in Facial Cosmetic Products," Journal of Chemical and Pharmaceutical Research, vol. 6, no. 8, pp. 561-564, 2014.

[8] J, A. Omolaoye, A. Uzairu, \& C. E. Gimba, "Heavy Metals Assessment on Some Ceramic Products Imported into Nigeria from China," Archives of Applied Science Research, vol. 2, no. 5, pp. 120-125, 2010.

[9] M. D. Faruruwa \& S. P. Bartholomew, "Study of Heavy Metals Content in Facial Cosmetics Obtained from Open Market and Superstores within Kaduna Metropolis, Nigeria," American Journal of Chemistry and Application, vol. 1, no. 2, pp. 27-33, 2014.

[10] Raimon, "Perbandingan Metode Destruksi Basah dan Kering secara Spektrofotometri Serapan Atom," diseminarkan pada Lokakarya Nasional Jaringan Kerjasama Kimia Analitik Indonesia, Yogyakarta, Indonesia, 1993.

[11] S. Kristianingrum, "Kajian Berbagai Proses Destruksi Sampel dan Efeknya," dalam Prosiding Seminar Nasional, Penelitian, Pendidikan dan Penerapan MIPA, 2012, 195-202.

[12] E. Rahmawati, D. C. Dewi, \& B. Fauziyah, "Analisis Kadar Logam Tembaga (Cu) pada Permen secara Spektrofotometri Serapan Atom (SSA)," Journal of Islamic Pharmacy, vol. 1, no. 1, pp. 11-14, 2015.

[13] E. N. Hidayati, "Perbandingan Metode Destruksi pada Analisis Pb dalam Rambut dengan AAS," Skripsi, Universitas Negeri Semarang, Semarang, 2013.

[14] A. N. Agusti, "Analisis Logam Timbal dan Tembaga terhadap Daya Serap Rumput Laut Gracilaria sp. Sebagai Biosorben," Skripsi, Universitas Islam Negeri Ar-Raniry, Banda Aceh, 2019.

[15] Taufikurrahman, "Penelitian Kadar Timbal (Pb) dan Tembaga (Cu) dalam Tanaman Rimpang Menggunakan Metode Destruksi Basah secara Spektroskopi Serapan Atom," Skripsi, Universitas Islam Negeri Maulana Malik Ibrahim, Malang, 2016.

[16] Y. S. Hidayat, "Penentuan Kadar Logam Timbal (Pb) dalam Coklat Batang Menggunakan Variasi Metode Destruksi dan Zat Pengoksidasi secara Spektrofotometri Serapan Atom (SSA)," Skripsi, Universitas Islam Negeri Mualana Malik Ibrahim, Malang, 2016.

[17] A. Yugatama, A. K. Mawarni, H. Fadillah, \& S. N. Zulaikha, "Analisis Kandungan Timbal dalam Beberapa Sediaan Kosmetik yang Beredar di Kota Surakarta," Journal of Pharmaceutical Science and Clinical Research, vol. 1, pp. 5259, 2019.

[18] F. Fatmawati \& Ayumulia, "Analisis Pb pada Sediaan Eyeshadow dari Pasar Kiaracondong dengan Metode Spektrofotometri Serapan Atom," Jurnal Kesehatan Bakti Tunas Husada, vol. 17, no. 2, pp. 227-233, 2017.

[19] Z. Kamal, M. Yazid, \& C. Supriyanto, "Penentuan Kadar Pb (Timbal) dalam Cat Rambut dengan Metode Spektofotometer Serapan Atom," pada Prosiding PPI - PDIPTN, 2005, pp. 82-86. 